\title{
Klinik Uygulamaya Çıkan Öğrenci Hemşirelerin İletişim Becerileri ve Etkileyen Faktörler
}

\author{
Communication Skills and Affecting Factors of Nursing Student Participating to \\ Clinical Practice
}

\author{
Hatice KAHYAOĞLU SÜT ${ }^{\mathrm{a}}$, Nazlı Gül DEMİR ${ }^{\mathrm{b}}$, Buse ÖZER $^{\mathrm{b}}$
}

\begin{abstract}
ÖZET Amaç: Çalışmada klinik uygulamaya çıkan öğrenci hemşirelerin iletişim beceri düzeylerinin belirlenmesi ve iletişim becerilerini etkileyen faktörlerin incelenmesi amaçlanmıştır. Gereç ve Yöntem: Araştırmamız Şubat-Mart 2014 tarihleri arasında Trakya Üniversitesi Sağlı Bilimleri Fakültesinde yürütülen kesitsel ve tanımlayıcı özellikte bir araştırmadır. Araştırmaya klinik uygulamaya çıkan, iletişim ile ilgili dersi almış ve araştırmaya katılmaya gönüllü hemşirelik bölümü 2, 3, 4. sınıf öğrencilerinden 179 öğrenci dahil edildi. Verilerin toplanmasında araştırmacılar tarafından hazırlanan, öğrencilerin çeşitli sosyo-demografik tanımlayıcı özelliklerinin ve iletişimle ilgili düşüncelerinin sorgulandığı bir anket formu ve iletişim becerilerini

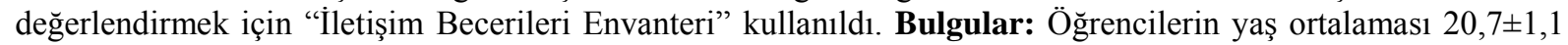
ve $\% 90,5$ 'i kadın olup alkol kullanma oran $\% 12,8$ 'dir. \%87,2'si insanlarla, $\% 91,1$ 'i hastalarla iletişimlerinin iyi olduğunu düşünmekte, hasta ile iletişimde sorun yaşayanların oranı \%17,9'dur. Öğrencilerin \%59,2'si klinik uygulamalarda sağlık personelinin olumsuz davranışlarının hasta ile iletişimini olumsuz etkilediğini düşünmektedir. Öğrencilerin iletişim becerileri envanterinin alt boyut skorlarından en yüksek skoru "zihinsel beceri" alt boyutundan $(59,1 \pm 6,2)$, en düşük skoru "duygusal beceri" alt boyutundan $(53,0 \pm 5,5)$ elde edildi. Alkol kullanmayanların "zihinsel beceri" skoru $(59,5 \pm 6,0)$ alkol kullananlardan $(56,2 \pm 6,6)$ anlamlı olarak yüksek bulundu $(\mathrm{p}=0,035)$. Okulda iletişim ile ilgili alınan derslerin yararlı olduğunu düşünenlerin "zihinsel beceri $(\mathrm{p}=0,012)$ ", "davranıssal beceri $(\mathrm{p}=0,020)$ " ve "toplam beceri $(\mathrm{p}=0,046)$ " skoru anlamlı olarak yüksek bulundu, "duygusal beceri $(\mathrm{p}=0,448)$ " skorunda fark bulunmadı. İnsanlarla iletişimlerinin iyi olduğunu düşünen öğrencilerin "davranışsal becerì" skoru anlamlı olarak yüksek bulundu $(\mathrm{p}=0,018)$. Benzer șekilde, hastalarla iletişimlerinin iyi olduğunu düşünen öğrencilerin "davranışsal beceri" skorları da anlamlı olarak yüksek bulundu $(\mathrm{p}=0,010)$. Sonuç: Klinik uygulamaya çıkan öğrenci hemşirelerin iletişim becerileri değerlendirildiğinde hastalar ve insanlarla olan iletişimlerine ilişsin olumlu düşünceye sahip olanların davranışsal iletişim becerilerinin, alkol kullanmayanların ise zihinsel iletişim becerilerinin daha yüksek olduğu gözlenmişstir. Ayrıca, okulda iletişimle ilgili alınan dersler zihinsel ve davranışsal iletişim becerilerini yükselterek toplam iletişim becerisini iyileştirmektedir.
\end{abstract}

Anahtar kelimeler: Öğrenci hemşire, iletişim becerisi, hasta, klinik uygulama

ABSTRACT Aim: In this study, it was aimed to investigate that communication skills and affecting factors of nursing student participating to clinical practice. Material and Methods: Our research conducted as crosssectional and descriptive features at the Trakya University, Faculty of Health Sciences between February and March 2014. One hundred and seventy-nine 2nd, 3rd, and 4th year nursing students who learned communication course, volunteered to study and participated into clinical practice were included. Socio-demographic and communication characteristics were collected by using a survey form designed by researchers and communication skills of students were obtained by using "Communication Skills Inventory". Results: Average age was $20.7 \pm 1.1,90.5 \%$ was women, alcohol consumption rate was $12.8 \%, 87.2 \%$ thought that their communication with people was good, $91.1 \%$ thought that their communication with patients was good, $17.9 \%$ had problems communicating with patients. $59.2 \%$ of the students thought that negative behavior of health staff in clinical practices negatively affected to their communication with the patient. The highest subscale score of

Geliş Tarihi/Received: 27.11.2014 Kabul Tarihi/ Accepted: 01.28.2015

${ }^{a}$ Yrd.Doç. Dr.Trakya Üniversitesi Sağlık Bilimleri Fakültesi, Kadın Sağlığı ve Hastalıkları Hemşireliği Anabilim DalıEdirne

' Trakya Üniversitesi Sağlık Bilimleri Fakültesi, Hemşirelik Bölümü Öğrencisi-Edirne

Yazışma adresi/Coresspondence :Yrd.Doç.Dr. Hatice Kahyaoğlu Süt, Trakya Üniversitesi Sağlık Bilimleri Fakültesi, Kadın Sağlığı ve Hastalıkları Hemşireliği Anabilim Dalı 22030 - Edirne haticesut@ yahoo.com

*Çalışma 1-3 Mayıs 2014 tarihleri arasında Trabzon'da düzenlenen 13.Ulusal Öğrenci Hemşire Kongresinde poster bildiri olarak sunulmuştur. 
the Communication Skills Inventory was cognitive skills $(59.1 \pm 6.2)$ while the lowest subscale score was emotional skills $(53.0 \pm 5.5)$. Cognitive skills score of students who not used alcohol $(59.5 \pm 6.0)$ was significantly higher than those used alcohol $(56.2 \pm 6.6)(\mathrm{P}=0.035)$. "Cognitive skills $(\mathrm{p}=0.012)$," "behavioral skills $(\mathrm{p}=0.020)$ " and "total skills $(\mathrm{p}=0.046)$ " scores of students thinking that learned communication lessons in the school was helpful were significantly higher, however, it was not significantly differ in "emotional skills ( $\mathrm{p}=$ 0.448)" score. "Behavioral skills" score was significantly higher $(\mathrm{p}=0.018)$ in students thought that their communication with people was good. Similarly, "behavioral skills" score was also significantly higher $(\mathrm{p}=$ 0.010) in students thought that their communication with patients was good. Conclusion: When the communication skills of nursing student participating to clinical practice are evaluated, individual behavioral skills is higher in students thought that their communication with patients and people was good and cognitive skills is higher in students who not used alcohol. Also, thinking that learned communication lessons in the school were helpful improves overall communication skills upgrading of cognitive and behavioral skills.

Keywords: Nursing student, communications skill, patients, clinical practice

\section{Giriş}

İletişim, iki kişinin duygu, düşünce ve bilgilerini paylaşarak birbirini anlamasını sağlayan bir süreçtir. Mesleki yaşamda ise iletişim, bir kurum içerisinde verimli, etkin şekilde olması gereken ve beraberinde başarıyı, anlayışı, sağlıklı iletişim davranışlarını getiren bir süreçtir. İletişim becerisi ise, kişinin duygu, düşünce, inanç ve tutumlarını anlaşılır ve amaca uygun bir şekilde aktarabilme becerisidir. ${ }^{1-3}$

Etkili iletişim becerileri, her türlü insan ilişkisinde ve bütün meslek alanlarında ilişkileri kolaylaştırabilmektedir. ${ }^{4,5}$ Kişilerarası etkileşimin özünü oluşturan iletişim bütün bireylerin yaşamlarında önemlidir. Meslek çalışanlarının başarıları da mevcut iletişim becerilerinden etkilenir. $^{4,6,7}$ Hemşirelikte ise iletişim becerilerinin geliştirilmesi ilk olarak eğitim süreci içerisinde olur., ${ }^{2,8}$

Hemşirelik öğrencileri, okulda aldığ 1 teorik bilgileri klinik uygulama alanlarında pratik bilgiye dönüştürerek 4 yıllık uygulamalı eğitim görmektedir. ${ }^{9}$ Klinik uygulama alanları hemşirelik öğrencilerine meslektaşlarını gözlemleme, tek başına uygulama yaparak sorumluluk alabilme, karar verme ve bir ekip üyesi olarak çalışabilmesini, okul ortamında öğretilen teorik ve pratik bilgiyi klinik ortamda uygulamalı olarak bütünleştirme imkanı verir. ${ }^{10-12} \mathrm{Bu}$ süreçte öğrencinin gerekli tüm bilgi ve teknik becerileri öğrenmesi, etkili kişilerarası ilişkiler kurma, danışmanlık becerileri gibi nitelikli hemşirelik hizmetlerinin önemli bir unsuru olan temel becerileri öğrenmesi gerekmektedir. ${ }^{13}$
Hemşireler bakım hizmetlerinde hasta ve hasta yakınları ile sürekli iletişim içerisindedir ve hemşirelerin hastalarını bakım hizmetleri yönünden memnun edebilmeleri için etkili iletişim becerilerine sahip olması gerekir. ${ }^{4}$ Hemşirelerin iletişim becerilerinin iyi olmasının (hasta ve diğer bireylerle iyi iletişime sahip olmalarının) hastaların memnuniyet, hastalık ve tedaviye uyum, motivasyon artışı gibi pozitif etki yarattığı yapılan çalışmalarda gösterilmiştir. ${ }^{14,15}$ Kişilerarası ilişkilerin son derece önemli olduğu hemşirelik mesleğini seçen öğrencilerin de meslek yaşamlarına başlamadan klinik uygulama alanlarında eğitimleri devam ederken, eğitim programlarının iletişim becerilerini geliştirecek ş̧ekilde düzenlenmesi gerekmektedir. ${ }^{15,16}$

Araştırmamızda klinik uygulamaya çıkan öğrenci hemşirelerin iletişim beceri düzeylerinin belirlenmesi ve iletişim becerilerini etkileyen faktörlerin incelenmesi amaçlanmaktadır.

\section{Araştırmanın soruları:}

- Klinik uygulamaya çıan Öğrenci hemşirelerin iletişim beceri düzeyleri nasıldir?

- Klinik uygulamaya çıkan öğrenci hemşirelerin iletişim becerilerini etkileyen faktörler nelerdir?

\section{Gereç ve Yöntem}

Araştırmanın Tipi: Çalışmamız kesitsel ve tanımlayıcı özellikte olup, Şubat-Mart 2014 tarihlerinde Trakya Üniversitesi Sağlık Bilimleri Fakültesi Hemşirelik Bölümü 2., 
3., 4. sınıf öğrencilerinden $(n=347)$ klinik uygulamaya çıkan, iletişim ile ilgili dersi almış (kişilerarası ilişkiler dersi), çalışmaya katılmaya gönüllü olan $\mathrm{n}=179$ öğrenci üzerinde yürütüldü.

Veri Toplama Araçları: Verilerin toplanmasında araştırmacılar tarafindan hazırlanan ve öğrencilerin çeşitli sosyodemografik tanımlayıcı özelliklerinin ve iletişimle ilgili düşüncelerinin sorgulandığ 1 bir anket formu ile "İletişim Becerileri Envanteri” kullanıldı.

İletişim Becerileri Envanteri: Ersanlı ve Balcı tarafından 1998 yılında geliştirilen "İletişim Becerileri Envanteri" her biri 5 seçenekli likert tipi (Her zaman=5, Genellikle $=4$, Bazen $=3$, Nadiren $=2$ ve Hiçbir zaman=1) cevaplar içeren 45 maddeden ve 3 alt boyuttan (zihinsel, duygusal ve davranışsal) oluşmaktadır. Alt boyutların her biri $15^{\prime}$ 'er madde içermektedir.1,3,6,12,15,17,18,20,23,24,26, 28,33,37,45. maddeler ölçeğin "zihinsel beceriler" alt boyutunu, 5, 9, 11, 27, 29, 31, $34,35,36,38-40,42-44$. maddeler ölçeğin "duygusal beceriler" alt boyutunu, 2, 4, 7, 8, 10, 13, 14, 16, 19, 21, 22, 25, 30, 32, 41. maddeler ölçeğin "davranışsal beceriler" alt boyutunu sorgulamaktadır. Ölçek puanlarının hesaplanması alt boyutlara giren maddelerin toplam puanlarının hesaplanmasına dayalıdır, $15^{\prime}$ er madde içeren her bir alt ölçekten alınabilecek en yüksek puan 75 en düşük puan ise 15 'dir. Toplam puan benzer şekilde 45 maddenin toplanmasiyla bulunur ve alınabilecek en yüksek puan $225^{\prime}$ dir. Yüksek puan bireyin daha iyi iletişim becerisine sahip olduğunu gösterir. ${ }^{17}$

Verilerin Analizi: Araştırma sonuçları Ortalama \pm Standart Sapma ya da Sayı (Yüzde) olarak gösterildi. Niceliksel verilerin normal dağılıma uygunluğu Tek Örneklem Kolmogorov Smirnov Test ile incelendi. İletişim Becerileri Envanterine Güvenirlik Analizi (Reliability Analysis) uygulanarak Croncach alfa katsayısı hesapland1. Ölçeğe ilişkin Cronbach's alpha katsayıs1 0,78 olarak bulundu ve buna göre ölçek oldukça güvenilir olarak değerlendirildi. İki kategoriden oluşan değişkenlerin kategorileri arasında ölçek skorlarının karşılaştırılmasında Mann Whitney U Testi kullanıld1. Kategori sayıs1 ikiden fazla olan değişkenlerin kategorileri arasında ölçek skorlarının karşılaştırılmasında ise Kruskal Wallis Testi kullanıldı, anlamlı farklılık bulunduğunda farklılığın hangi kategoriler arasında olduğunu belirlemede ise Bonferroni düzeltmeli Mann Whitney U Testi kullanıldı. Yaş ile ölçek skorları arasındaki ilişkileri incelemede Spearman Korelasyon Analizi kullanıldı. İstatistiksel analizler SPSS 20.0 istatistiksel paket programı kullanılarak yapıldı. İstatistiksel anlamlılık sınır değeri olarak $\mathrm{p}<0.05$ kabul edildi.

Araştırmanın Etik Yönü: Anketin öğrenciler üzerinde uygulanabilmesi için Trakya Üniversitesi Sağlık Bilimleri Fakültesi Dekanlığından yazılı izin alınmıştır. Öğrenciler anketi doldurmadan önce çalışmanın amacı açıklanmış olup anketi doldurmayı kabul eden gönüllüler çalışmaya dahil edildi.

\section{Bulgular}

Çalışmaya katılan $\mathrm{n}=179$ öğrencinin yaş ortalamas1 $20,7 \pm 1,1, \quad \% 90,5$ 'ini k1z öğrenciler oluşturmaktadır. Öğrencilerin büyük çoğunluğunun yaşadığı yer ilçe, şehir ve büyükşehir iken, \%14'lük kısmının köydür. Anne ve baba eğitimine baktığımızda, annelerin \%83,8'i, babaların $\% 59,8$ 'i ilköğretim ve alt1 eğitim düzeyindedir. Üniversite eğitimleri sırasında ögrencilerin \%38'i devlet yurdunda, \%6,7'si ise aileleriyle birlikte yaşamaktadır. Öğrencilerin \%8,9'unun sigara, \%12,8'inin alkol kullanmaktadır. \%69,3'ü hemşirelik bölümünü isteyerek tercih etmiş olup tercih nedenlerinin başında $(\% 61,5)$ kolay iş bulabileceğini düşünüyor olmaları gelmektedir. Öğrencilerin \% $\% 5,4$ 'ü hemşirelik bölümde okumaktan memnundurlar (Tablo 1). 
Tablo 1. Hemşirelik öğrencilerinin incelenen sosyo-demografik tanımlayıcı özellikleri

\begin{tabular}{|c|c|c|c|}
\hline & & $\mathrm{n}$ & $\%$ \\
\hline \multirow{2}{*}{ Cinsiyet } & $\mathrm{K}_{1 \mathrm{z}}$ & 162 & 90,5 \\
\hline & Erkek & 17 & 9,5 \\
\hline \multirow{5}{*}{ Yaşadığı yer } & Köy & 25 & 14,0 \\
\hline & Kasaba & 14 & 7,8 \\
\hline & İlçe & 49 & 27,4 \\
\hline & Şehir & 45 & 25,1 \\
\hline & Büyükşehir & 46 & 25,7 \\
\hline \multirow{5}{*}{ Mezun olunan lise } & Düz & 95 & 53,1 \\
\hline & Anadolu & 74 & 41,3 \\
\hline & Sağlık meslek & 1 & 0,6 \\
\hline & Meslek & 8 & 4,5 \\
\hline & Öğretmen & 1 & 0,6 \\
\hline \multirow{3}{*}{ Sınıf düzeyi } & II & 83 & 46,4 \\
\hline & III & 75 & 41,9 \\
\hline & IV & 21 & 11,7 \\
\hline \multirow{2}{*}{ Anne eğitim } & İlköğretim ve altı & 150 & 83,8 \\
\hline & Lise ve üstü & 29 & 16,2 \\
\hline \multirow{2}{*}{ Baba eğitim } & İlköğretim ve altı & 107 & 59,8 \\
\hline & Lise ve üstü & 72 & 40,2 \\
\hline \multirow{5}{*}{$\begin{array}{l}\text { Üniversite eğitimi } \\
\text { sırasında kalınan yer }\end{array}$} & Aile & 12 & 6,7 \\
\hline & Devlet yurdu & 68 & 38,0 \\
\hline & Özel yurt & 45 & 25,1 \\
\hline & Evde tek & 6 & 3,4 \\
\hline & Evde ark & 48 & 26,8 \\
\hline \multirow{2}{*}{ Sigara kullanım durumu } & Evet & 16 & 8,9 \\
\hline & Hayır & 163 & 91,1 \\
\hline \multirow{2}{*}{ Alkol kullanım durumu } & Evet & 23 & 12,8 \\
\hline & Hayır & 156 & 87,2 \\
\hline \multirow{2}{*}{$\begin{array}{l}\text { Hemşirelik bölümünü } \\
\text { isteyerek mi tercih ettiği }\end{array}$} & Evet & 124 & 69,3 \\
\hline & Hayır & 55 & 30,7 \\
\hline \multirow{4}{*}{$\begin{array}{l}\text { Hemşirelik bölümünü } \\
\text { tercih nedeni }\end{array}$} & Sevdiğim için & 47 & 26,3 \\
\hline & Aile istediğinden & 20 & 11,2 \\
\hline & Kolay iş & 110 & 61,5 \\
\hline & Diğer & 2 & 1,1 \\
\hline \multirow{2}{*}{$\begin{array}{l}\text { Hemşirelik bölüm } \\
\text { memnuniyeti }\end{array}$} & Evet & 135 & 75,4 \\
\hline & Hayır & 44 & 24,6 \\
\hline
\end{tabular}

Öğrencilerin iletişimle ilgili çeşitli düşüncelerini sorguladığımızda; \%87,2'si insanlarla, \%91,1'i hastalarla iletişimlerinin iyi olduğunu düşünmekte olup, hasta ile iletişimde sorun yaşayanların oranı \%17,9'dur. Öğrencilerin \%59,2'si klinik uygulamalarda sağlık personelinin olumsuz davranışlarının hasta ile iletişimlerini olumsuz etkilediğini düşünmektedir. Okulda alınan iletişim ile ilgili derslerin klinik uygulamalarında faydalı olduğunu düşünen öğrencilerin oran1 \%33'dür (Tablo 2). 
Tablo 2. Öğrencilerin iletişimle ilgili çeşitli düşüncelerinin sorgulanma dağılımı

\begin{tabular}{|l|l|c|c|}
\hline & & $\mathrm{n}$ & $\%$ \\
\hline \multirow{2}{*}{$\begin{array}{l}\text { İnsanlar ile iletişiminizin iyi olduğunu düşünüyor } \\
\text { musunuz? }\end{array}$} & Evet & 156 & 87,2 \\
\cline { 2 - 4 } & Hayır & 23 & 12,8 \\
\hline \multirow{2}{*}{$\begin{array}{l}\text { Hastalar ile iletişiminizin iyi olduğunu düşünüyor } \\
\text { musunuz? }\end{array}$} & Evet & 163 & 91,1 \\
\cline { 2 - 4 } & Hayır & 16 & 8,9 \\
\hline \multirow{2}{*}{ Hasta ile iletişimde sorun yaşıyor musunuz? } & Evet & 32 & 17,9 \\
\cline { 2 - 4 } & Hayır & 147 & 17,9 \\
\hline $\begin{array}{l}\text { Klinik uygulamaları sırasında, uygulama alanında } \\
\text { çalışan sağlık personelinin size olan davranışları, } \\
\text { sizin hasta ile iletişiminizi olumsuz etkiliyor mu? }\end{array}$ & Hayır & 73 & 40,8 \\
\cline { 2 - 4 } $\begin{array}{l}\text { Okulda iletişim ile ilgili almış olduğunuz derslerin } \\
\text { klinik uygulama alanında size yararı olduğunu } \\
\text { düşünüyor musunuz? }\end{array}$ & Evayır & 106 & 59,2 \\
\cline { 2 - 4 } & Evet & 34 & 19,0 \\
\cline { 2 - 4 } & Kısmen & 86 & 48,0 \\
\hline
\end{tabular}

Öğrencilerin iletişim becerileri envanterinin alt boyut skorları ve toplam skoruna baktığımızda; en yüksek skor zihinsel beceriler alt boyutundan
$(59,1 \pm 6,2)$ elde edilirken en düşük skor duygusal beceriler alt boyutundan $(53,0 \pm 5,5)$ elde edilmiştir (Tablo 3).

Tablo 3. İletişim becerileri envanterinin alt boyut ve toplam skoru

\begin{tabular}{|l|c|c|c|}
\hline & Ortalama \pm SD & Minimum & Maksimum \\
\hline Zihinsel Beceriler & $59,1 \pm 6,2$ & 43 & 75 \\
\hline Duygusal Beceriler & $53,0 \pm 5,5$ & 39 & 71 \\
\hline Davranışsal Beceriler & $55,8 \pm 5,8$ & 38 & 69 \\
\hline Toplam Skor & $168,0 \pm 14,5$ & 122 & 209 \\
\hline
\end{tabular}

Öğrencilerin yaş, cinsiyet, yaşanılan yer, anne ve baba eğitimi, sınıf düzeyi, sigara ve alkol kullanma durumu ile iletişim becerileri envanterinin alt boyut skorları ve toplam skoru karşılaştırıldığında; sadece alkol kullanmayanların zihinsel beceri skoru $(59,5 \pm 6,0)$ alkol kullananlardan $(56,2 \pm 6,6)$ anlamlı olarak yüksek bulundu $(\mathrm{p}=0,035)$. Bunun dışında yaş, cinsiyet, yaşanılan yer, anne ve baba eğitim durumu, sınıf düzeyi, sigara kullanma durumu değişkenlerinin zihinsel beceri ( $\mathrm{p}>0,05)$, duygusal beceri ( $\mathrm{p}>0,05)$, davranışal beceri $(\mathrm{p}>0,05)$ ve toplam beceri $(\mathrm{p}>0,05)$ ölçek skorlarını etkilemediği bulundu (Tablo 4). 
Tablo 4. Öğrencilerin incelenen sosyo-demografik tanımlayıcı özellikleri ile iletişim becerileri envanterinin alt boyut skorları ve toplam skorunun karşılaştırılması

\begin{tabular}{|c|c|c|c|c|c|}
\hline & & $\begin{array}{l}\text { Zihinsel } \\
\text { Beceriler }\end{array}$ & $\begin{array}{l}\text { Duygusal } \\
\text { Beceriler }\end{array}$ & $\begin{array}{c}\text { Davranışsal } \\
\text { Beceriler }\end{array}$ & $\begin{array}{c}\text { Toplam } \\
\text { Skor }\end{array}$ \\
\hline \multirow[t]{3}{*}{ Cinsiyet } & Kadın $(n=162)$ & $59,3 \pm 5,9$ & $53,0 \pm 5,4$ & $55,9 \pm 5,7$ & $168,3 \pm 13,9$ \\
\hline & Erkek $(\mathrm{n}=17)$ & $56,7 \pm 8,3$ & $53,2 \pm 6,6$ & $55,0 \pm 7,4$ & $165,0 \pm 19,5$ \\
\hline & $\mathrm{p}$ & 0,077 & 0,959 & 0,567 & 0,244 \\
\hline \multirow{6}{*}{$\begin{array}{l}\text { Yaşanılan } \\
\text { yer }\end{array}$} & Köy $(n=25)$ & $58,9 \pm 6,8$ & $52,7 \pm 5,9$ & $55,2 \pm 5,8$ & $166,8 \pm 15,0$ \\
\hline & Kasaba $(n=14)$ & $57,4 \pm 6,6$ & $52,4 \pm 6,1$ & $55,6 \pm 6,2$ & $165,5 \pm 16,9$ \\
\hline & İlçe $(\mathrm{n}=49)$ & $60,1 \pm 6,2$ & $54,3 \pm 5,2$ & $57,2 \pm 6,4$ & $171,7 \pm 14,0$ \\
\hline & Şehir $(n=45)$ & $58,6 \pm 6,7$ & $53,2 \pm 5,1$ & $55,5 \pm 5,6$ & $167,3 \pm 14,7$ \\
\hline & Büyükşehir $(n=46)$ & $59,0 \pm 5,3$ & $51,8 \pm 5,8$ & $55,0 \pm 5,1$ & $165,9 \pm 13,5$ \\
\hline & $\mathrm{p}$ & 0,516 & 0,307 & 0,250 & 0,292 \\
\hline \multirow{3}{*}{$\begin{array}{l}\text { Anne } \\
\text { eğitimi }\end{array}$} & İlkögretim ve altı $(n=150)$ & $59,0 \pm 6,0$ & $52,8 \pm 5,6$ & $55,6 \pm 5,7$ & $167,5 \pm 14,2$ \\
\hline & Lise ve üstü $(n=29)$ & $59,4 \pm 7,3$ & $54,3 \pm 5,2$ & $56,8 \pm 6,4$ & $170,5 \pm 16,0$ \\
\hline & $\mathrm{p}$ & 0,697 & 0,223 & 0,201 & 0,334 \\
\hline \multirow{3}{*}{$\begin{array}{l}\text { Baba } \\
\text { eğitimi }\end{array}$} & İlköğretim ve altı $(n=107)$ & $59,3 \pm 6,3$ & $52,8 \pm 5,7$ & $55,9 \pm 6,1$ & $168,1 \pm 14,8$ \\
\hline & Lise ve üstü $(n=72)$ & $58,7 \pm 6,1$ & $53,3 \pm 5,4$ & $55,6 \pm 5,5$ & $167,7 \pm 14,0$ \\
\hline & $\mathrm{p}$ & 0,552 & 0,516 & 0,662 & 0,934 \\
\hline \multirow{4}{*}{$\begin{array}{l}\text { Sinıf } \\
\text { düzeyi }\end{array}$} & II $(n=83)$ & $59,1 \pm 5,5$ & $53,4 \pm 5,5$ & $55,5 \pm 5,5$ & $168,0 \pm 13,6$ \\
\hline & III $(n=75)$ & $59,6 \pm 6,8$ & $52,9 \pm 5,6$ & $56,5 \pm 6,1$ & $169,0 \pm 15,2$ \\
\hline & IV $(n=21)$ & $57,2 \pm 6,5$ & $51,7 \pm 5,4$ & $54,7 \pm 6,0$ & $163,8 \pm 15,2$ \\
\hline & $x^{2}-1-7$ & 0,363 & 0,542 & 0,348 & 0,484 \\
\hline \multirow{3}{*}{$\begin{array}{l}\text { Sigara } \\
\text { kullanımı }\end{array}$} & Hayır $(n=163)$ & $59,3 \pm 6,2$ & $52,9 \pm 5,6$ & $56,0 \pm 5,8$ & $168,3 \pm 14,7$ \\
\hline & Evet $(n=16)$ & $56,6 \pm 6,0$ & $53,8 \pm 4,3$ & $53,6 \pm 5,7$ & $164,1 \pm 12,0$ \\
\hline & $\mathrm{p}$ & 0,078 & 0,455 & 0,144 & 0,215 \\
\hline \multirow{3}{*}{$\begin{array}{l}\text { Alkol } \\
\text { kullanımı }\end{array}$} & Hayır $(n=156)$ & $59,5 \pm 6,0$ & $53,0 \pm 5,6$ & $56,1 \pm 5,5$ & $168,8 \pm 14,3$ \\
\hline & Evet $(n=23)$ & $56,2 \pm 6,6$ & $53,3 \pm 4,8$ & $53,8 \pm 7,3$ & $163,3 \pm 15,5$ \\
\hline & $\mathrm{p}$ & $\mathbf{0 , 0 3 5}$ & 0,816 & 0,357 & 0,132 \\
\hline Yaş* & & $\begin{array}{c}\mathrm{r}=-0,038 ; \\
\mathrm{p}=0,618\end{array}$ & $\begin{array}{l}\mathrm{r}=0,004 ; \\
\mathrm{p}=0,956\end{array}$ & $\begin{array}{l}\mathrm{r}=0,012 ; \\
\mathrm{p}=0,869\end{array}$ & $\begin{array}{l}\mathrm{r}=0,002 ; \\
\mathrm{p}=0,976\end{array}$ \\
\hline
\end{tabular}

* Spearman korelasyon analizi

Öğrencilerin iletişimle ilgili düşünceleri ile iletişim becerileri envanterinin alt boyut skorları ve toplam skorunun karşılaştırılmasına baktığımızda; okulda iletişim ile ilgili alınan derslerin yararlı olduğunu düşünenlerin "zihinsel beceri $(\mathrm{p}=0,012)$ ", "davranışsal beceri $(\mathrm{p}=0,020)$ " ve "toplam beceri $(\mathrm{p}=0,046)$ " skoru anlamlı olarak yüksek bulundu, "duygusal beceri $(\mathrm{p}=0,448)$ " skorunda fark bulunmadi. Okulda iletişim ile ilgili alınan derslerin klinik uygulama alanında yararı olduğunu düşünenlerin, zihinsel, davranışsal ve toplam beceri skorları hayır ve k1smen yanıtı verenlerden anlamlı olarak yüksek bulundu $(\mathrm{p}<0,05)$. Kismen ve hayır yanitı verenler arasında zihinsel, davranışsal ve toplam beceri skorları açısından anlamlı fark bulunmadi $\quad(p>0,05)$ İnsanlar ile iletişimlerinin iyi olduğunu düşünenlerin davranışsal beceri skoru, iyi olmadığını düşünenlerden anlamlı olarak yüksek bulundu $\quad(p=0,018)$ İnsanlar ile iletişimlerinin iyi olduğunu düşünenlerin zihinsel beceri ve toplam beceri skorlar1, iyi olmadığını düşünenlerden yüksek fakat istatistiksel anlamlılığa yakın bulundu ( $\mathrm{p}=0,065$ ve $\mathrm{p}=0,057)$. İnsanlar ile iletişimlerinin iyi olduğunu düşünenlerin ve düşünmeyenlerin duygusal beceri skorları arasında anlamlı fark bulunmadı $(\mathrm{p}=0,627)$. Hastalar ile iletişimlerinin iyi olduğunu 
düşünenlerin davranışsal beceri skoru, iyi olmadığını düşünenlerden anlamlı olarak yüksek bulundu $(\mathrm{p}=0,010)$. Hastalar ile iletişimlerinin iyi olduğunu düşünenlerin zihinsel beceri ve toplam beceri skorları iyi olmadığını düşünenlerden yüksek fakat istatistiksel anlamlılığa yakın bulundu ( $p=0,081$ ve $p=0,136)$. Hastalar ile iletişimlerinin iyi olduğunu düşünenlerin ve düşünmeyenlerin duygusal beceri skoru arasında anlamlı fark bulunmad $1(\mathrm{p}=0,450)$ (Tablo 5).

Tablo 5. Öğrencilerin iletişimle ilgili düşünceleri ile iletişim becerileri envanterinin alt boyut skorları ve toplam skorunun karşılaştırılması

\begin{tabular}{|c|c|c|c|c|c|}
\hline & & $\begin{array}{c}\text { Zihinsel } \\
\text { Beceriler }\end{array}$ & $\begin{array}{c}\text { Duygusal } \\
\text { Beceriler }\end{array}$ & $\begin{array}{c}\text { Davranışsal } \\
\text { Beceriler }\end{array}$ & $\begin{array}{c}\text { Toplam } \\
\text { Skor }\end{array}$ \\
\hline \multirow{2}{*}{$\begin{array}{l}\text { Okulda iletişim ile ilgili alınan } \\
\text { derslerin yararı olduğunu } \\
\text { düşünüyor musunuz? }\end{array}$} & Hayır & $57,7 \pm 7,2$ & $53,7 \pm 6,2$ & $53,3 \pm 7,3$ & $164,8 \pm 18,3$ \\
\cline { 2 - 6 } & Kısmen & $58,3 \pm 5,8$ & $52,6 \pm 5,5$ & $55,8 \pm 5,1$ & $166,8 \pm 13,5$ \\
\cline { 2 - 6 } & Evet & $60,9 \pm 5,8$ & $53,2 \pm 5,1$ & $57,2 \pm 5,5$ & $171,4 \pm 12,8$ \\
\hline \multirow{2}{*}{$\begin{array}{l}\text { İnsanlar ile iletişiminizin iyi } \\
\text { olduğunu düşünüyor musunuz? }\end{array}$} & Hayır & $57,2 \pm 6,1$ & $52,9 \pm 6,9$ & $53,4 \pm 5,6$ & $163,6 \pm 15,6$ \\
\cline { 2 - 6 } & Evet & $59,3 \pm 6,2$ & $53,0 \pm 5,3$ & $56,1 \pm 5,8$ & $168,6 \pm 14,3$ \\
\hline \multirow{2}{*}{$\begin{array}{l}\text { Hastalar ile iletişiminizin iyi } \\
\text { olduğunu düşünüyor musunuz? }\end{array}$} & Evet & $59,2 \pm 6,3$ & $52,9 \pm 5,4$ & $56,1 \pm 5,8$ & $168,4 \pm 14,5$ \\
\cline { 2 - 6 } & Hayır & $57,1 \pm 5,3$ & $54,1 \pm 6,8$ & $52,4 \pm 5,4$ & $163,6 \pm 14,3$ \\
\hline \multicolumn{1}{|c|}{$p$} & & 0,081 & 0,450 & $\mathbf{0 , 0 1 0}$ & 0,136 \\
\hline
\end{tabular}

\section{Tartışma}

Öğrenci hemşirelerin iletişim beceri düzeylerinin belirlenmesi, klinik uygulamalarda iletişim becerilerini etkileyen faktörlerin incelenmesi, mezuniyet öncesi iletişim becerilerini artırmaya yönelik eğitim gereksinimlerinin saptanması açısından önemlidir.

\section{Çalışmamızda}

öğrencilerin \%75,4'ünün hemşirelik bölümde okumaktan memnun olduğu, \%69,3'ünün hemşirelik bölümünü isteyerek tercih ettiği ve tercih nedenlerinin başında $(\% 61,5)$ kolay iş imkanı düşüncesi olduğu bulunmuştur (Tablo 1). Hemşirelik bölümü öğrencileri üzerinde yürütülen bir çalışmada öğrencilerin \%71,4'ünün hemşire olmaya istekli oldukları ve hemşirelik mesleğini orta derecede prestijli bulduğu için tercih ettiğ belirlenmiştir. $^{18}$ Ünlü ve arkadaşlarının ${ }^{19}$ yaptığı çalışmada öğrencilerin \%56,0’’nın mesleği severek tercih ettiği, \%42,7'sinin iş bulma imkanının fazla olması nedeniyle tercih ettiği belirlenmiştir. Günümüzde sağlık alanında çalışacak hemşire ihtiyacının fazla olması nedeniyle mezuniyet sonrası işe girme sürecinin diğer meslek gruplarına göre daha hızlı ve kolay olması gibi etkenlerin öğrencilerin hemşirelik bölümünü isteyerek tercih etmelerinde önemli rolü olduğu düşünülmektedir.

Öğrencilerin iletişimle ilgili çeşitli düşüncelerini sorguladığımızda; öğrencilerin $\% 87,2$ 'si insanlarla, \%91,1'i hastalarla iletişimlerinin iyi olduğunu düşünmekte olup, hasta ile iletişimde sorun yaşayanların oranı \%17,9 olduğu bulunmuştur (Tablo 2). Tutuk ve arkadaşlarının ${ }^{14}$ çalışmasına göre ögrencilerin $\% 37,2$ si insanlarla ilişkilerinde güçlük yaşadıklarını, klinikte hasta ve hasta yakınları ile iletişim sorunu yaşama konusunda klinik deneyimi olmayan 
birinci sınıf öğrencileri dışındaki öğrencilerin \%12,6' sının çok fazla sorun yaşadığını bildirilmişken, \%65,8' inin ise zaman zaman sorun yaşadığını ifade ettiği bildirilmiştir. Genel olarak baktığımızda hemşirelik bölümünü tercih eden öğrencilerin çoğunluğunun insanlarla ve hastalarla iletişimlerinin iyi olduğunu düşündüğü görülmektedir.

$$
\text { Öğrencilerin \%59,2'si klinik }
$$

uygulamalarda sağlık personelinin olumsuz davranışlarının hasta ile iletişimlerini olumsuz etkilediğini düşündüğü bulunmuştur (Tablo 2). Klinik uygulamaya çıkan (2., 3., 4. sınıf) 162 hemşirelik öğrencisi üzerinde yürütülen bir çalışmada, öğrencilerin yalnızca \% $3.1^{\prime} i$ klinik hemşirelerinin kendileriyle olan iletişimlerini "iyi" olarak, \% 53.1' i "ne iyine kötü", \% 43.8'i ise "kötü" ya da "çok kötü" olarak ifade ettiği belirlenmiştir. ${ }^{20}$ Akyüz ve arkadaşlarının ${ }^{21}$ çalışmasında hemşirelerin çalışma süreleri yükseldikçe öğrencilerin klinikteki varlıklarının iş yükünü arttırdığını düşünme oranının arttığı belirlenmiştir. Öğrenci hemşirelerin servis hemşireleri ile olan iletişim eksikliğinden dolayı klinik uygulamalarına isteyerek katılmadıkları, aynı çalışma da hemşirelerin öğrenci hemşirelerle beraber uygulama yaparken öğrencilerin hata yapmasından endişe duyduklarını ( $\%$ 69) ifade ettikleri belirlenmiştir. $^{22}$ Klinik hemşirelerinin ve sağlık personelinin yoğun çalışma koşulları, öğrenci hemşirelere klinik uygulamalarda hata yapmamaları için takip etmek zorunda olmaları gibi nedenlerle öğrencileri ek bir iş yükü olarak görmeleri, öğrencilerle iletişim sorunu yaşamalarına ve bu durumunda öğrencilerin hasta ile olan iletişimini olumsuz etkilemesine sebep olduğu düşünülmektedir.

Çalışmamızda okulda alınan iletişim ile ilgili derslerin klinik uygulamalarda faydalı olduğunu düşünen öğrencilerin oranı \%33'dür (Tablo 2). Sabancığulları ve arkadaşlarının $^{23}$ çalışmasında iletişim becerilerinin lisans eğitimiyle geliştiği saptanmıştır. 4. Sınıf hemşirelik öğrencilerinin iletişim becerilerinin 1. Sınıf öğrencilerinden daha yüksek belirlendiği bir çalışmada, 1 . ve 2 . sinıfta yer alan genel ve mesleki iletişim dersleri ve diğer derslerde iletişimle ilgili konular vurgulanmasının eğitimin öğrencilerin iletişim becerilerinin gelişmesine olumlu katkı sağladığı şeklinde bildirmişlerdir. ${ }^{14}$ Ayrıca hemşirelik eğitimi sırasında uygulamalı hemşirelik derslerinde hasta-hemşire iletişimine yönelik eğitim verilmesinin hasta memnuniyetini olumlu yönde etkilediği bildirilmiştir. ${ }^{4}$ Klinikte hasta-hemşire iletişiminin önemi nedeniyle mezuniyet öncesi eğitim sürecinde iletişimle ilgili konuların ve derslerin müfredatta yer alması, öğrenci hemşirelerin iletişim becerilerini klinik uygulamalarda etkin kullanabilmeleri açısından öğrenciler tarafından önemsendiği görülmektedir.

Çalışmamızda öğrencilerin incelenen sosyo-demografik tanımlayıcı özellikleri (yaş, cinsiyet, yaşanılan yer, anne ve baba eğitim durumu, sınıf düzeyi, sigara ve alkol kullanma durumu) ile iletişim becerileri envanterinin alt boyut skorları ve toplam skoru karşılaştırmasında sadece alkol kullanmayanların zihinsel beceri skoru alkol kullananlardan anlamlı olarak yüksek bulundu (Tablo 4). İncelenen diğer sosyodemografik tanımlayıcı özelliklerin zihinsel, duygusal, davranışsal ve toplam beceri ölçek skorlarını etkilemediği bulundu. Yapılan diğer çalışmalarda da çalışmamızın sonuçlarına benzer şekilde öğrencilerin incelenen sosyo-demografik özelliklerinin iletişim becerilerini etkilemediği belirlenmiştir. Ancak bu çalışmalarda alkol kullanımı ile iletişim becerileri arasındaki ilişkiye bakılmamıştır. ${ }^{15,24}$ Çalışmamız sonucuna göre alkol kullanan öğrencilerin zihinsel beceri skorunun düşük bulunması, alkol kullanımının öğrenci hemşirelerin zihinsel iletişim becerilerini olumsuz yönde etkilediğini göstermektedir.

Çalışmamızda öğrencilerin lisans eğitiminde sınıf düzeylerinin zihinsel, duygusal, davranışsal ve toplam beceri ölçek skorlarını etkilemediği bulundu (Tablo 4). Bingöl ve arkadaşının ${ }^{15}$ çalışmasında dört yıllık lisans eğitimi sonrasında iletişim becerilerinde artış yönünde dördüncü sınıf 
lehine anlamlı fark beklenirken, fark olmadığı belirlenmiş ve ders müfredatının iletişim becerileri yönünden tekrar gözden geçirilmesi gerektiğini bildirmişlerdir. Hemşirelik öğrencilerinin iletişim becerilerine yönelik bir çalışma da sınıf düzeyi ile iletişim becerileri düzeyi arasındaki ilişkinin anlamlı bulunduğu ve birinci sınıftan üçüncü sınıfa kadar sınıf düzeyi arttıkça iletişim becerilerinde artış olduğu belirlenmiştir. ${ }^{14}$ Ülkemiz hemşirelik lisans eğitimi veren okullarında müfredatta iletişim ile ilgili derslere ve konulara yer verildiğinde iletişim becerilerindeki artışın sınıf düzeyi ile paralel olarak artabileceği, müfredatta iletişim ile ilgili derslere ve konulara yer verilmemesi durumunda ise iletişim becerilerinin sinif düzeyinden etkilenmeyebileceği düşünülmektedir.

Çalışmamızda öğrencilerin okulda iletişim ile ilgili aldıkları derslerin yararlı olduğunu düşünme durumlarının zihinsel, davranissal ve toplam beceri skorunu etkilediği, duygusal beceri skorunu ise etkilemediği bulundu (Tablo 5). Yapilan bazı çalışmalarda ise iletişim becerilerinin lisans eğitimiyle geliştiği saptanmıştır. ${ }^{20,24}$ Genel olarak baktığımızda öğrencilerin okulda iletişimle ilgili aldıkları derslerin yararlı olduğunu düşünmelerinin iletişim becerilerini olumlu yönde etkilediği söylenebilir.

Okulda iletişim ile ilgili alınan derslerin klinik uygulama alanında yararı olduğunu düşünenlerin, zihinsel, davranışsal ve toplam beceri skorlar1 hayır ve k1smen yanıtı verenlerden anlamlı olarak yüksek bulundu (Tablo 5). Birinci sınıf hemşirelik öğrencileri ile yapılan bir çalışmada, öğrencilerin mesleki eğitime başlarken iletişim becerileri yönünden kısmen gelişmiş oldukları bildirilmiștir. ${ }^{14}$ Kumcağız ve arkadaşlarının $^{4}$ çalışmasında lisans ve üzeri eğitimin, hemşirelerin iletişim becerilerinin davranışsal boyutunu olumlu yönde etkilediği saptanmıştır. Öğrencilerin iletişim ile ilgili derslerin klinik uygulamalarda yararlı olduğunu düşünmeleri iletişim becerilerini olumlu yönde etkilemekte ve lisans eğitim düzeyinin mezuniyet sonrasında iletişim becerileri üzerinde olumlu etkisinin olduğu görülmektedir.

İnsanlar ile iletişimlerinin iyi olduğunu düşünenlerin davranışsal beceri skoru, iyi olmadığını düşünenlerden anlamlı olarak yüksek bulundu (Tablo 5). Bir çalışmada öğrencilerden insanlarla ilişkilerinde güçlük yaşadığını bildirenlerin iletişim becerilerinin, güçlük yaşamadığını bildirenlere göre daha iyi olduğu belirlenmiştir. ${ }^{14}$ Buradan insanlarla iletişimlerinin iyi olduğunu düşünmenin davranışlara da olumlu yönde yansıdığ 1 söylenebilir.

Hastalar ile iletişimlerinin iyi olduğunu düşünenlerin davranışsal beceri skoru, iyi olmadığını düşünenlerden anlamlı olarak yüksek bulundu (Tablo 5). Bir çalışmada

klinik uygulamalarda iletişimde güçlük yaşadığını bildirenler ile güçlük yaşamadığını bildirenler arasında iletişim becerileri açısından fark olmadığ belirlenmiştir. ${ }^{14}$ Hastalar ile iletişimlerinin iyi olduğunu düşünmenin davranışlara da olumlu yönde yansıdığını fakat klinik uygulamalarda öğrencilerin iletişim becerilerini etkin kullanmalarını engelleyen başka faktörlerin olabileceği söylenebilir.

\section{Sonuç ve Öneriler}

Klinik uygulamaya çıkan öğrenci hemşirelerin iletişim becerileri değerlendirildiğinde, hastalar ve insanlarla olan iletişimlerine ilişkin olumlu düşünceye sahip öğrencilerin davranışsal iletişim becerileri, alkol kullanmayanların ise zihinsel iletişim becerileri daha yüksek olup, okulda iletişimle ilgili alınan dersler zihinsel ve davranışsal iletişim becerisini yükselterek toplam iletişim becerisini iyileştirir.

Elde edilen sonuçlar doğrultusunda aşağıdaki sonuçlar önerilebilir:

1. Mevcut hemşirelik lisans eğitimi ders müfredatı yeniden gözden geçirilerek, iletişim ile ilgili eğitim içeriği ve uygulamalı eğitim yöntemlerinin ders müfredatındaki konulara sinıfların düzeylerine uygun olacak şekilde düzenli yerleştirilmesi, 
2. Diksiyon ve hitabet, psikodrama, yaratıc1 drama vb. zihinsel, duygusal ve davranışsal iletişim becerilerinin etkin kullanılmasını ve artırılmasını sağlayacak derslerin müfredatta seçmeli ya da zorunlu ders olarak eklenmesi ve bu alanlarda uzman eğitimciler tarafindan uygulamalı olarak derslerin verilmesi,

3. Alkol vb. zararlı alışkanlıklar konusunda mezuniyet öncesi öğrencilerin farkındalığını artırmak amacıyla iletişim ders konuları içerisinde "alkol ve iletişim" konusuna da yer verilmesi gerekliliği önerilmektedir.

\section{Yazarların Katkıları}

Çalışma tasarımı: H KS, NG D, BÖ

Veri toplama ve/ veya analizi: H KS, NG D, BÖ

Makalenin hazırlanması: H KS, NG D, BÖ

\section{Kaynaklar}

1. Üstün B. Çünkü iletişim Çok Şeyi Değiştirir. Atatürk Üniversitesi Hemşirelik Yüksekokulu Dergisi 2005; 2: 88-94.

2. Tiryaki HŞ, Taşkın FY, Pekşen ÖÜ. Hizmet İçi Eğitim Hemşirelerinin İletişim Beceri Düzeyleri. Journal of Psychiatric Nursing 2013;4(1):13-20

3. Çelik Ç. İlköğretim okulu müdürlerini iletişim becerileri ile tükenmişlik düzeyleri arasındaki ilişki (Gaziantep İli Merkez İlçeleri Örneği). [Yayınlanmamış yüksek lisans tezi] Gaziantep: Gaziantep Üniversitesi Sosyal Bilimler Enstitüsü; 2007.

4. Kumcağız H, Yılmaz M, Çelik SB, Avcı İA. Hemşirelerin iletişim becerileri: Samsun ili örneği. Dicle Tıp Dergisi 2011; 38 (1): 49-56

5. Korkut F. Yetişkinlere yönelik iletişim becerileri eğitimi. Hacettepe Üniversitesi Eğitim Fakültesi Dergisi 2005; 28: 143-149.

6. Uyer G. Hemşire - Hasta İletişimi ve İletişimin Hasta Yönünden Önemi. Türkiye Klinikleri Tıp Etiği 2000; 8: 8894.
7. Yılmaz S, Hacıhasanoğlu R, Çiçek Z. Hemşirelerin genel ruhsal durumlarının incelenmesi. Sted 2006; 15:92-97.

8. Suikkala A, Leino-Kilpi H. Nursing student-patient relationship: a review of the literature from 1984 to 1998 . J Adv Nurs 2001;33:42-50.

9. Aydın MF, Argun MŞ. Bitlis Eren Üniversitesi Sağlık Yüksekokulu Hemşirelik Bölümü Öğrencilerinin Hastane Uygulamalarından Beklentileri ve Karşılaştıkları Sorunlar. Acıbadem Üniversitesi Sağlık Bilimleri Dergisi 2010; (1):4

10. Karadağ G, Kılıç SP, Ovayolu N, Özlem Ovayolu, Hülya Kayaaslan $\mathrm{H}$. Öğrenci Hemşirelerin Klinik Uygulamada Karşılaştıkları Güçlükler ve Klinik Hemşireler Hakkındaki Görüşleri. TAF Prev Med Bull 2013;12(6):665-672

11. Atay S, Yılmaz F. Sağlık yüksekokulu öğrencilerinin ilk klinik stres düzeyleri. Anadolu Hemşirelik ve Sağlık Bilimleri Dergisi 2011; 14(4): 32-37

12. Dunn SV, Hansford B. Undergraduate nursing students' perception of their clinical learning environment. J Adv Nurs. 1997; 25(6):1299-306.

13. Arifoğlu B, Razı GS. Birinci Sınıf Hemşirelik Öğrencilerinin Empati ve İletişim Becerileriyle İletişimYönetimi Dersi Akademik Başarı Puanı Arasındaki İlişki. DEUHYO ED 2011,4(1): 7-11

14. Tutuk A, Al D, ve Doğan S. "Hemşirelik Öğrencilerinin İletişim Becerisi ve Empati Düzeylerinin Belirlenmesi". C. Ü. Hemşirelik Yüksek Okulu Dergisi 2002;6:36-41.

15. Bingöl G, Demir A. Amasya sağlik yüksekokulu öğrencilerinin iletişim becerileri. Göztepe Tip Dergisi 2011; 26(4):152-159.

16. Kuzu A. "Hemşirelik Öğrencilerinin Duygusal Zeka ve İletişim Becerilerin Eşdeğer Öğrenim Gören Öğrencilerle Karş1laştırmalı Olarak Değerlendirilmesi” Düzce Üniversitesi, Sağlık Bilimleri Enstitüsü. 
(Yayımlanmamış Yükseklisans Tezi), Düzce, (2008).

17. Ersanlı K, Balcı S. İletişim Becerileri Envanterin Geliştirilmesi: Geçerlik ve Güvenirlik Çalışması. Türk Psikolojik Danışma ve Rehberlik Dergisi 1998;2(10):7-12.

18. Erbil N, Kahraman AN, Bostan Ö. Hemşirelik Öğrencilerinin İlk Klinik Deneyim Öncesi Anksiyete Düzeylerinin Belirlenmesi. Atatürk Üniversitesi Hemşirelik Yüksekokulu Dergisi 2006; 9(1).

19. Ünlü $S$, Özgür $G$, Gümüş $A B$. Hemşirelik yüksekokulundaki öğrencilerin hemşirelik mesleği ve eğitimi ile ilgili görüş ve beklentileri. E.Ü. Hemşirelik Yüksekokulu Dergisi 2008; 24(1): 43-56.

20. Kaya A, Gözüm S, Kaya A, Ünsal A, Unlu F. Hemşirelik Öğrencileri Gözüyle Klinik Hemşireleri. Atatürk Üniversitesi Hemşirelik Yüksekokulu Dergisi 2000;3(1).

21. Akyüz A, Tosun N, Yıldız D, Kılıç A. Klinik Öğretimde Hemşirelerin, Kendi
Sorumluluklarına ve Hemşirelik Öğrencilerinin Çalışma Sistemine İlişkin Görüşleri. TSK Koruyucu Hekimlik Bülteni 2007;6(6).

22. Aydın MF, Argun MŞ. Bitlis Eren Üniversitesi Sağlik Yüksekokulu Hemşirelik Bölümü Öğrencilerinin Hastane Uygulamalarından Beklentileri ve Karşılaştıkları Sorunlar. Acıbadem Üniversitesi Sağlık Bilimleri Dergisi 2010;1(4).

23. Sabanc1oğulları S, Kelleci M, Doğan S, Gölbaşı Z. Entegre Eğitim Programında Öğrenim Gören Hemşirelik Öğrencilerinin Empatik Eğilim Düzeylerinin Y1llara Göre İncelenmesi. C.Ü Hemşirelik Yüksekokulu Dergisi 2007;11(2):1-6.

24. Tepeköylü Ö, Soytürk M, Çamliyer H. Beden Eğitimi ve Spor Yüksekokulu (Besyo) Öğrencilerinin İletișim Becerisi Algılarının Bazı Değişkenler Açısından İncelenmesi, Spormetre Beden Eğitimi ve Spor Bilimleri Dergisi, 2009;7:115124. 